\title{
THE INVESTIGATION RESULTS OF A MULTILAYERED SITE OF KAYA ARASY
} IN CRIMEA

(C) 2014

\author{
S.A. Telizhenko, Candidate of Historical Sciences, researcher \\ A.P. Veselsky, Candidate of Historical Sciences, researcher \\ Institute of Archaeology, National Academy of Sciences of Ukraine, Kiev (Ukraine)
}

Annotation: During the archaeological research of a multilayer Kaya Arasy site of Crimea, a clear stratigraphical sequence of cultural layers was established, that are corresponding to the diverse archaeological contexts. In addition, the material from the previous excavations by the A.A. Schepinskii and A.A. Formozov was analyzed and combining those two datasets the stratigraphic sequence of the Kaya Arasy site was established. The material of the site is currently stored in the Bakhchisaray Historical and Cultural Reserve; however, it was not organized according to the periods and the stratigraphical units. The research presented in this paper allowed to attribute this abandoned material to the chronological sequence of the Kaya Arasy site.

Key words: Crimea; stratigraphy; Neolithic; flint assemblage.

УДК 902.2

(C)2014

\section{САЗАГАНСКАЯ КУЛЬТУРА (НЕОЛИТ СРЕДНЕГО ЗАРАФШАНА)}

\author{
Н.У. Холматов, кандидат исторических наук, доцент \\ Самаркандский государственный университет, Самарканд (Узбекистан)
}

Аннотация: Статья посвящена проблемам и перспективам исследования памятников, которые датируются неолитическим возрастом на территории Зарафшанской долины. Есть вопросы, в свете новых материалов, которые связаны с изучением сазаганской культуры, в частности ее генезиса и культурных связей.

Ключевые слова: Тянь-Шань; Средний Зарафшан; Самаркандская стоянка; Сазаган 1,2; Аякагитма; скребки; орудия долотовидной формы; культурогенез.

В годы независимости Республики Узбекистан в исследовании материальной культуры каменного века сделан ряд принципиально важных открытий $[1 ; 2 ; 3 ; 4 ; 5]$. Анализ археологических материалов, полученных в результате комплексных мультидисциплинарных исследований памятников каменного века, позволяет выявить их приуроченность к обособленным природным территориальным комплексам - геофациям. В процессе изучения палеоэкологических проблем истории мезолита и неолита было обращено особое внимание на то, что территория Узбекистана занимает обширные пространства центральной части Евразии и представляет собой крупный физико-географический регион, который простирается от вершин Тянь-Шаня и Памира на востоке, до плато и низменных равнин с бессточными переуглубленными котловинами на западе. На востоке и юге его территория располагается в пределах орогена, входящего в горную структуру Высокой Азии, на севере и западе уходит в глубь Туранской плиты.

В свое время на основании комплексных исследований А.В. Виноградов и Э.Д.Мамедов предположили, что в Центральной Азии в раннем и среднем голоцене (VII-III тысячелетия до н.э.) был относительно мягкий (плювиальный) климат [6]. Животный и растительный мир был близким к современному. Поэтому в конце мезолита - начале неолита первобытным человеком были почти полностью освоены пригодные для обживания территории Центральной Азии. Однако люди оказывались в разных природных, экологических и климатических условиях - горных, предгорных, равнинных. Эти особенности оказывали влияние на развитие материальной культуры, хозяйства и быта. В результате возник ряд археологических культур, имеющих специфические особенности. В процессе изучения истории неолита Центральной Азии были выделены самостоятельные локальные археологические культуры, относящиеся к различным хронологическим этапам и расположенные в определенных природных геофациальных условиях. Так, памятники джейтунской культуры занимают небольшую узкую полосу подгорной равнины Копетдага [7]; Гиссарская - центральную и восточную части Памира [8; 9, с.105-123; 10]; Кельтеминарская историко-культурная общность занимает низовья Амударьи, территории Кызылкумов и староречьях Зарафшана [11]; Центрально-ферганская культура локализована в центральной части Ферганской депрессии [12]; Сазаганская культура занимает район Среднего Зарафшана в его горном обрамлении [13]; Устюртская культура - район плато Устюрт [14] (рис. $1)$.

Следует отметить, что в свое время В.А.Ранов для горных и предгорных районов Средней Азии наметил три географические области, которые занимают различные по своей материальной культуре группы: Гиссарскую, Маркансуйскую и Центрально-Ферганскую. А выделение других зон распространения иных локальных культур в горной и предгорной части Средней Азии он считал пока еще невозможным [15, с.19-20]. В противовес мнению В.А. Ранова об иных локальных культурах в горной и предгорной части Средней Азии мы считаем, что есть возможность на основе материалов вновь открытых стоянок выделить новую самостоятельную неолитическую археологическую культуру на территории Среднего Зарафшана. Это - Сазаганская культура.

В предлагаемой статье в краткой форме на основе новых археологических данных излагаются специфические особенности Сазаганской культуры. Результаты изучения культурогенеза, культурных связей, хозяйствования, духовной культуры важны для понимания истории развития культуры мезолита и неолита на территории Центральной Азии и, в частности, Узбекистана.

Для решения проблем истории заселения и развития материальной культуры каменного века перспективное значение имеет территория Узбекистана и, в частности, долина Зарафшана. Зарафшан, третья по величине река Средней Азии, берет начало в горах Тянь-Шаня (площадь бассейна 41880 км², протяженность 781 км). По ряду существенных признаков долина Зарафшана четко делятся на три части: верхний Зарафшан; Зарафшанская (или Самаркандская) впадина, (Средний Зарафшан) и континентальная дельта с многочисленными староречьями (Нижний Зарафшан). Зарафшанская впадина втянута в субмеридиональном направлении между отрогами Туркестанского и Зарафшанского хребтов, южная часть её ограничена западной оконечностью Зарафшанского хребта (горы Чакылкалян, Каратюбе и Зиадин-Зирабулак). Так, в долине Среднего Зарафшана исследованы сазаганская культура, в нижнем 
Зарафшане культуры Кельтеминарских общин. В 80-х годы прошлого века в изучении материальной культуры общности каменного века Зарафшанской долины эпохи мезолита и неолита были получены интересные археологические материалы. Так, в низовьях Зарафшана А.В. Виноградовым были открыты ряд развеянных мезолитических стоянок Чорбакты, Аякагитма, Дарясай, Эчкиликсай [11, с. 59]. В последующие годы мезолитические памятники Чорбактинской группы и полученные в этом районе археологические материалы были всесторонне изучены и введены автором в научный оборот. Учитывая наличие в инвентаре Чорбактинских стоянок ранней группы таких специфических для гор и предгорий типов, как долотовидные орудия, высокие скребки, отщепы с выемками, типичные галечные орудия, можно полагать, что эти данные оставлены выходцами из гор, не исключено, что из предгорий и низкогорий, обрамляющих Зарафшанскую впадину. Это подтверждается и отщепово-пластинчатым характером индустрии и типом использованного сырья [16, с.27-44]. Начиная с 1995 г. совместной узбекско-польской экспедицией изучается стоянка Аякагитма, работы на которой с 2005 года продолжены узбекскофранцузской экспедицией. По кремневым находкам и керамике памятник датирован концом эпохи мезолита и развитого неолита [2, с.244-250; 17, с.118-125].

В Среднем Зарафшане также исследуются стоянки сазаганской культуры. Так, археологическая экспедиция Самаркандского государственного университета ежегодно проводит свои исследования на северных склонах горного массива Каратюбе Среднего Зарафшана. Объектом исследования является изучение памятников Сазаганской неолитической культуры (рис.2).

Все стоянки сазаганской культуры расположены в полосе высот 900-1000 м. Небезынтересно то, что эти высоты соответствуют нижней границе распространения памятников гиссарской культуры в Южном Таджикистане. В свое время В.А. Ранов отметил, что «К северной окраине распространения или влияния гиссарской культуры можно отнести поселения Сазаган 2 , Джангал 1, расположенные на Среднем Зарафшане. С гиссарскими памятниками их сближают некоторые приёмы в индустрии, выразившиеся в наличии элементов галечной техники, а также каменные выкладки, имеющие, как в Туткауле, угольно-зольные пятна» [15, с.19].

Геолого-геоморфологические данные показывают, что террасовый комплекс сазаганской предгорной равнины и соответствующий ему комплекс террас Сазагансая сформировался в голодностепское сырдарьинское время. Третья терраса с сазаганскими стоянками относится, скорее всего, к голодностепскому времени, а оседание людей на ней датируется концом голодностепской - началом сырдарьинской эпох, то есть концом позднего плейстоцена или раннего голоцена. Эти выводы в настоящее время более соответствуют представлениям, полученным на основе археологических данных. Полученные в ходе раскопок материалы стоянок сазаганской культуры датируются концом мезолита и неолита. В результате проведенных комплексных исследований в среднем течении реки Зарафшан и его горного обрамления была выделена и научно обоснована своеобразная сазаганская неолитическая культура [13]. Тогда были известны лишь стоянки Сазаган 1,2 и Джангал 1. В последующие годы были продолжены исследования памятников Сазаганской культуры. Изучены новые стоянки Агалык, Замичатош [18], Тепакул 3, Тепакул 4, расположенные в разных долинах северных предгорий горного массива Каратюбе. Кроме того, обнаружены еще свыше двадцати стоянок открытого типа, изучение которых еще не начато, более десяти стоянок пещерного типа, в некоторых из которых обнаружены следы культур первобытного времени (Лолаб, Каракамар, Очилгор и т.д.) (рис. 2.). В процессе исследования этих стоянок были получены новые археологические материалы, Самарский научный вестник. 2014. № 3(8) которые дали возможность осветить и решить такие актуальные проблемы, касающиеся мезолита и неолита Зарафшанской долины, как культурные связи, культурогенез, зарождение производящего хозяйства. Исследования показали, что сазаганцы жили не изолированно, а имели культурные контакты с неолитическими племенами соседних территорий (Кельтеминар, Гиссар, Центральноферганская культура). Материалы из Сазагана дают возможность говорить о культурных контактах населения гор и равнин. Нами проведены типологические сравнения коллекций из Сазагана и с нижнего Зарафшана, результатом его были установление факта взаимопроникновения ряда изделий из камня. В частности, это небольшая группа изделий из ножевидных пластин с крутой укрепляющей ретушью с брюшка по обеим сторонам (реже - по одной). Эти орудия свойственны сейчас только для кельтеминарских коллекций низовьев Зарафшана и ряда других районов Кызылкумов, с одной стороны, и сазаганских коллекций, с другой. Получены также некоторые данные о формировании религиозных воззрений жителей Зеравшанской долины эпохи неолита [3, с. 90-98].

Дальнейшее изучение материалов сазаганской культуры затрагивает практически все основные проблемы археологии, в частности, проблемы палеоэкологии, хронологии, палеоклиматологии, a также целый комплекс физико-географических и историко-геологических направлений наук. В связи с этим актуальность приобретают результаты комплексного изучения одного из опорных памятников сазаганской культуры, давшего интересный материал, пещерной стоянки Очилгор, которая включает культурные отложения эпох мезолита и неолита.

Пещерная стоянка Очилгор расположена на северных склонах Каратюбинского массива, в бассейне правого притока p. Сазаган (абсолютная высота над уровнем моря 1108 м). Грот представляет собой большую округлую нишу, обращенную на юг. Ширина при входе 8,0 м, глубина - 10,5 м, максимальная высота свода - 3,6 м. Общая площадь

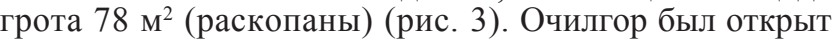
в 2003 г. археологическим отрядом Самаркандского государственного университета, возглавляемым М.Д. Джуракуловым. В 2004-2013гг. раскопки проводились под руководством Н.У.Холматова. Целями полевых исследованийбыликомплексныйанализархеологического объекта, его пространственное положение, особенности закарстованности района, литолого-фациальных, стратиграфических, палеогеографических и ряда других характеристик.

На основании изучения технико-типологического и статистического анализов каменной индустрии нам удалось разделить последовательность формирования культурных напластований пещеры Очилгор на два комплекса: 1 комплекс (слои 13-нижняя часть 11); 2 комплекс (слои 11-7, верхняя часть).

1 комплекс (слои 13-нижняя часть 11). В орудийном наборе нижнего горизонта четко прослеживается преемственность в отношении технико-типологической традиции верхнепалеолитического времени. Так, значительное место в инвентаре Самаркандской стоянки занимают крупные галечные орудия и пластины. Нуклеусы преимущественно призматические, отмечены и дисковидной формы. Среди скребков преобладают концевые на отщепах, высокой формы [19, с.63-71, рис.14;17;26]. Они напоминают аналогичные предметы из нижнего культурного горизонта Очилгор. Сходство существует также между долотовидными орудиями, пластинами и пластинками с ретушью. Орудийный набор нижнего культурного горизонта находит близкие аналогии с орудийными комплексами хорошо стратифицированных мезолитических памятников Узбекистана - Кушилиш [20], Обишир 1-5 [21, с.38-140], Мачай [22] и материалы Центрально-Ферганских [12, с.17- 
65], Чорбактинских [16, с.27-44] стоянок. За пределами Узбекистана - Туткаул, Ошханы [8]. Эти факты дают нам основание датировать нижний культурный горизонт Очилгора мезолитом.

2 комплекс (слои 11-7, верхняя часть). В верхнем культурном слое расчищен очаг, отдельные скопления костей животных, две каменные выкладки округлой формы диаметром около метра каждая. Следует отметить, что подобные каменные выкладки также отмечены в неолитическим слое Кангуртута [15, с.24-27]. Между четко сформированными группами каменных выкладок обнаружены останки горного козла с полным набором костей. Можно заключить, что наличие подобных «алтарю» каменных возвышений с костями жертвенного животного свидетельствует об уже сформировавшихся тотемистических религиозных воззрениях жителей Заравшанской долины эпохи неолита.

Орудийный набор верхнего культурного горизонта находит близкие аналогии с орудийными комплексами стоянок сазаганской культуры (Сазаган 2, Жангал 1, Тепакул 3, 4, Лолаб) [13, с.41-102; 3, с.90-98]. Это сходство, а также обнаруженная неолитическая керамика дает нам основание датировать верхний культурный горизонт Очилгора неолитом. Для нас важно и другое обстоятельство: по нижнему культурному горизонту наблюдается уменьшение конусовидных, дисковидных, призматических нуклеусов, микропластинок, пластинок с притупленным краем, пластинок со скошенным концом, концевых скребков на пластинках, ребристых пластинок, архаичных пластинок, высоких скребков, микроскребков, дисковидных орудий, скребел, резцов, микрочопперов. В то же время в верхнем культурном горизонте увеличиваются карандашевидные призматические нуклеусы, микронуклеусы, пластины и микропластины с ретушью, геометрические орудия, двусторонне обработанные наконечники стрел, скребки на отщепах, проколки на пластинах, шлифованные топоры, плитчатые скребки, галечные орудия. Это дает основание для определения хронологической последовательности слоев Очилгора от мезолита к неолиту.

В пещерной стоянке Очилгор наблюдается четкая последовательность культуросодержащих горизонтов (нижний - мезолит; верхний - неолит), включенных в непотревоженную, более чем метровую толщу рыхлых отложений. От нижних к верхним горизонтам прослеживается преемственность в динамике первичной и вторичной обработки каменной индустрии в хронологическом диапазоне IX-IV тыс. лет до н.э.

\section{Выводы}

1. Памятники, обнаруженные в долинах северного склона гор Каратюбе, в настоящее время в рамках «горного» неолита рассматриваются как самостоятельные историко-культурные образования. Новые материалы, найденные в данном регионе, не противоречат этому, а наоборот, дополняют характеристику сазаганской культуры (VII-VI-III тыс. до н.э.).

2. Непрерывные исследования стоянок сазаганской культуры показали эволюционную преемственность культур каменного века Среднего Зарафшана. В этом плане особый интерес представляет впервые открытая и исследованная палеолитическая стоянка Олмабулок в районе села Сазаган. Сосредоточение на такой небольшой территории столь разновременных памятников, как Олмабулок (средний палеолит), Сазаган 1, Замичатош, Коракамар, Очилгор (нижний горизонт), - мезолит; Сазаган 2, Джангал 1, Тепакул 3,4,5, Лолаб, Очилгор (верхний горизонт) - неолит, - дает возможность проследить последовательное историческое развитие данного региона, начиная с мустьерской эпохи до неолита На основании имеющихся материалов можно предположить, что формирование сазаганской культуры произошло на основе местных культур типа палеолитической стоянки Олмабулок, Самаркандской верхнепалеоли192 тической стоянки, мезолитических стоянок Чорбакты, Сазаган 1, Замичатош, Коракамар, Очилгор (нижний горизонт). Стало ясно, что неолитическая сазаганская культура образовалась и развивалась на основе культур мезолитических памятников и является автохтонной.

3. Проблема судьбы сазаганской культуры ещё более сложна, так как в этом районе отсутствуют хорошо выделяемые поздненеолитические материалы. Но археологические материалы последних лет со стоянок Тепакул 3,4 , а также их типологический анализ подтверждают версию о том, что это поздние этапы сазаганской культуры. Это выражается в увеличении доли пластин и микропластин, выемчатых пластин, пластин со скошенным концом, низких скребков, призматических и конических нуклеусов для пластинок и микропластин, плитчатых скребков, галечных орудий, зернотерок. Сокращение количества нуклеусов торцевого типа, высоких скребков, изделий долотовидной формы является свидетельством перехода от более раннего к более позднему этапу освоения северных предгорий Каратюбе. Таким образом, стоянки Тепакул 3,4 , которые представляют собой поздний этап сазаганской культуры при анализе материалов Саразма (Верхний Зарафшан), позволяют сделать некоторые выводы о том, что предметы материальной культуры (пластинчатая часть каменной индустрии, керамики, зернотерки) находят близкие соответствия в артефактах энеолитических слоях Саразма [23].

Нам представляется, что недалеко то время, когда будет найден ключ к решению проблемы автохтонного развития саразмской культуры.

\section{СПИСОК ЛИТЕРАТУРЫ}

1. Деревянко А.П., Кривошапкин А.И., Славинский В.С., Анойкин А.А., Врин П., Чикишева Т.А., Милютин К.И., Колобова К. А. Анализ каменной индустрии и антропологических находок из слоя 16 грота Обирахмат (Республика Узбекистан) // Проблемы каменного века Средней и Центральной Азии. Новосибирск: Изд-во ИАЭт СО РАН, 2003. Т.9. Ч.1 С. $63-73$.

2. Хужаназаров М., Брунет Ф., Шимчак. Археологические исследования ЎзбекистонскоФранцузской экспедиции на памятниках Қизилкумов // Археологические исследования в Ўзбекистане 20042005 годы. Тошкент, 2006. С. 244-250.

3. Холматов Н.У. Неолит Каратюбе Среднего Зарафшана // Цивилизации и культуры Центральной Азии в единстве и многообразии. Самарканд-Ташкент, 2010. С. 90-97.

4. Деревянко А.П., Исламов У.И., Колобова К.А., Флас Д., Павленок К.К., Мухторов Г.А. Верхний палеолит Узбекистана: Стоянка Кулбулак // История Материальной Культуры Узбекистана. № 38. Самарканд, 2012. С. 18-37.

5. Деревянко А.П., Исламов У.И., Кривошапкин А.И., Колобова К.А. Верхний палеолит Узбекистана: Стоянка Додекатым // История Материальной Культуры Узбекистана. № 38. Самарканд, 2012. - С. 37-57.

6. Виноградов А.В., Мамедов Э.Д. Первобытный Лявлякан. М.: Наука, 1975. 271 с.

7. Массон В.M. Поселение Джейтун (проблема становления производящей экономики). Л.: Наука, 1971. 206c.

8. Ранов В.А. Памир и проблема заселения высокогорной Азии человеком каменного века // Страны и народы Востока. Вып.16. М.: Наука, 1975. С. 136-157.

9. Ранов В.А. Гиссарская культура - неолит горных областей Средней Азии// Каменный век Северной, Средней и Восточной Азии. Новосибирск: Наука. 1985. С. 27-28.

10. Ранов В.А. Неолит (гиссарская культура) // История таджикского народа. Т.1. Душанбе: Дониш, 1998. - С. 105.

11.Виноградов А.В. Древние охотники и рыболовы Среднеазиатского междуречья. М.: Наука, 1981. 172 с.

12. Исламов У.И., Тимофеев В.И. Культура каменного века Центральной Ферганы. Ташкент: Фан, 1986. 304 с. ил. 23 см.

13. Джуракулов М.Д., Холматов Н.У. Мезолит и Самарский научный вестник. 2014. № 3(8) 
неолит Среднего Зарафшана. Ташкент: Фан, 1991. 124 с.

14. Бижанов Е.Б. Каменный век Устюрта. Нукус:, 1996. 223 c.

15. Виноградова Н.М., Ранов В.А., Филимонова Т.Г. Памятники Кангурттута в Юго-Западном Таджикистане (эпоха неолита и бронзового века). М.: Ин-т востоковедения РАН, 2008. 472 c.

16. Холматов Н.У. Мезолит и неолит Нижнего Зарафшана. Ташкент: Фан, 2007. 203 с.

17. Брунет Ф., Хўжаназаров М, Хошимов Х. Новые данные к хронологии Кельтеминарской культуры в Узбекистане // История Материальной Культуры Узбекистана. № 38. Самарканд, 2012. С. 118-125.

18. Худойбердиев Р.А. Гречкина Т.Ю. Замича-тош
- Новый памятник каменного века // Палеоэкология и проблемы первобытной археологии Центральной Азии. Тезис докладов конференции, Самарканд, 1992. С. 122-125.

19. Джуракулов М.Д. Самаркандская стоянка и проблемы верхнего палеолита в Средней Азии. Тошкент: Фан, 1987. 174 с.

20. Исламов У.И. Мезолитическая стоянка Кушилиш под Ташкентом // Общественные науки Узбекистана. 1970. № 7. С. 54-57.

21. Исламов У.И. Обиширская культура. Ташкент: Фан, 1980. 178 с.

22. Исламов У.И. Пещера Мачай. Ташкент: Фан, 1975. $174 \mathrm{c}$.

23. Исаков А. Саразм. Душанбе: Дониш, 1991. 244 с.

\section{ИЛЛЮСТРАЦИИ}

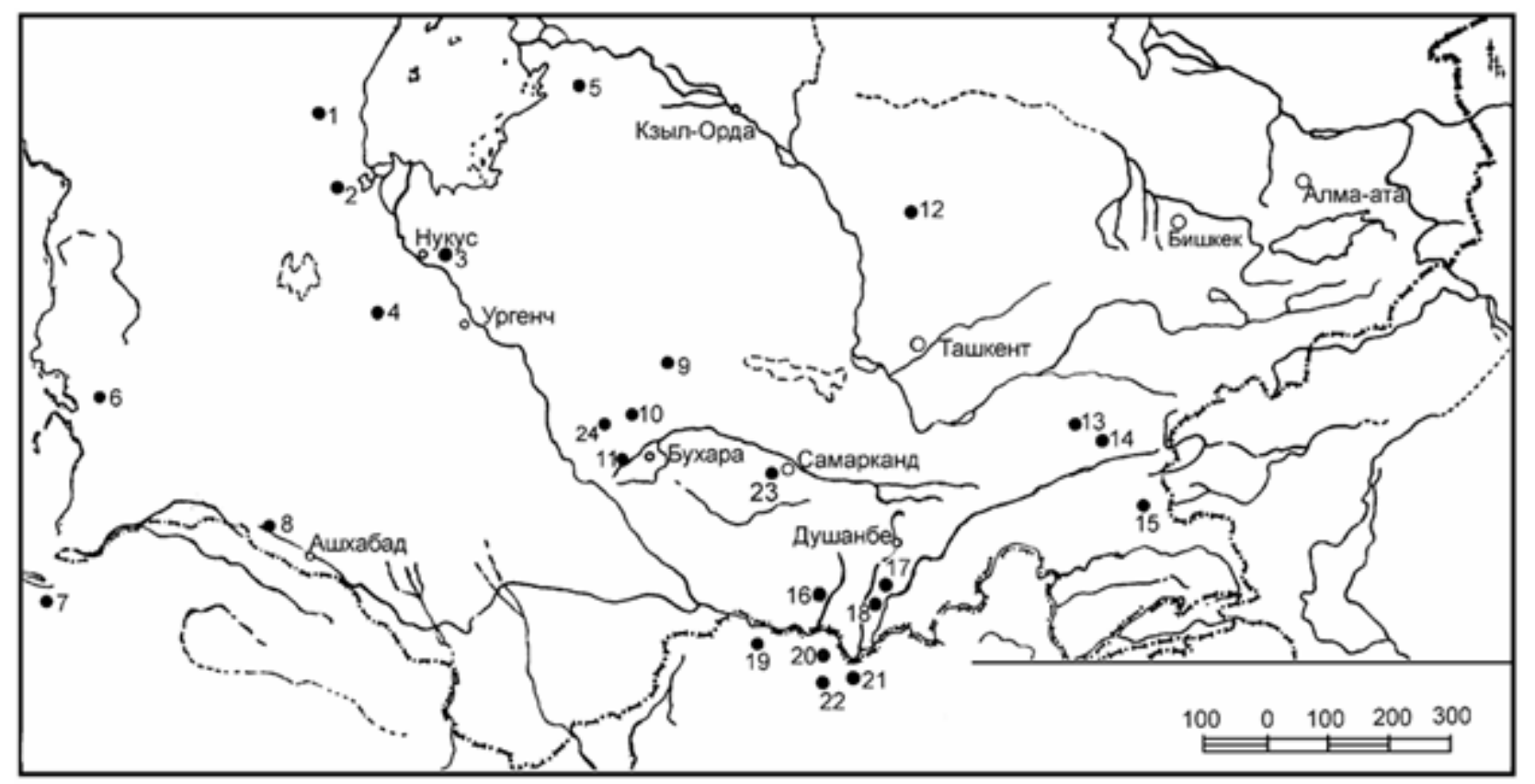

Рис. 1. Карта расположения неолитических памятников Средней Азии. 1,2 - Устюрт, 3 - Калтаминар, 8 - Джейтунская культура, 13,14 - Центрально-Ферганская культура, 16,17,18 - Гиссарская культура, 23Сазаганская культура

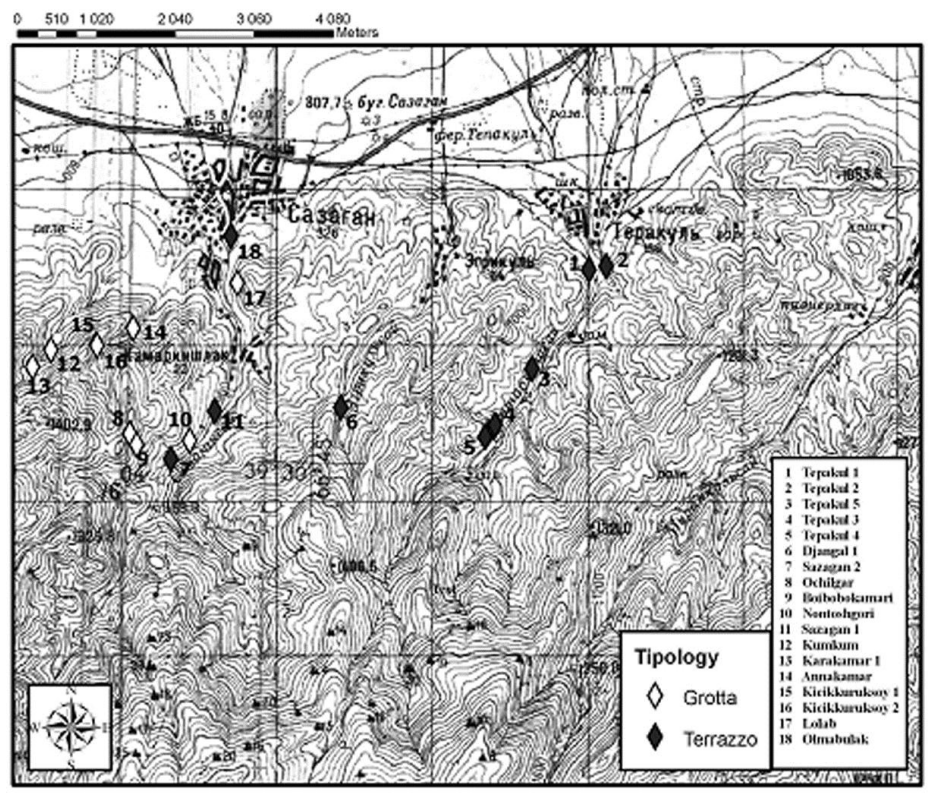

Рис. 3. Карта расположения памятников каменного века Карятюбе (Средний Зарафиан) 
Таблица 1 - Тип лист Очилгор

\begin{tabular}{|c|c|c|c|c|c|c|c|c|c|c|c|c|c|c|}
\hline Типы нзделнй & 0,7 & 0,8 & 0,9 & 1,0 & 1,1 & 1,2 & 1,3 & 1,4 & 1,5 & 1,6 & 1,7 & 1,8 & 1,9 & 2,0 \\
\hline & 7 & 8 & 9 & & 10 & 11 & & 12 & & 13 & & & & \\
\hline Отщепы, обломки, чешуйкн без ретушн & 1 & 12 & 11 & 23 & 24 & 34 & 31 & 20 & 113 & 20 & 31 & 13 & 22 & 365 \\
\hline Ножевидные пластины без ретуши & & 6 & 2 & 4 & 4 & 6 & 4 & 7 & 4 & 4 & 11 & 2 & 1 & 55 \\
\hline в том писте smpontactunnt & & 1 & & 1 & & 2 & 3 & 5 & 4 & 1 & 3 & & & 20 \\
\hline Нуклеусы & & & 1 & & & 5 & 1 & 1 & 2 & 5 & 2 & 3 & 1 & 21 \\
\hline 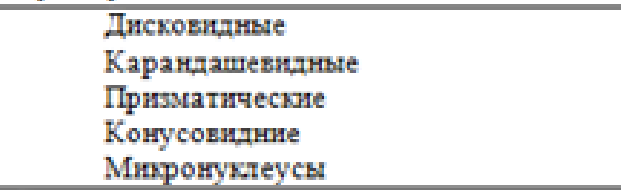 & & & 1 & & & $\begin{array}{l}- \\
- \\
2 \\
2 \\
1\end{array}$ & 1 & 1 & $\begin{array}{l}- \\
- \\
- \\
1 \\
1\end{array}$ & $\begin{array}{l}2 \\
3 \\
- \\
-\end{array}$ & $\begin{array}{l}1 \\
1\end{array}$ & 1 & 1 & \\
\hline Сколы с нуклеусов & & & & & 1 & & 1 & 5 & 4 & & & 1 & & 12 \\
\hline Bcezo & & & & & & & & & & & & & & 453 \\
\hline \multicolumn{15}{|c|}{ Нзделия из ножезиднысх птастин: } \\
\hline $\begin{array}{l}\text { Птастины с ретушью со стинии по обеим } \\
\text { сторонам }\end{array}$ & & 1 & 2 & 4 & 3 & 3 & 3 & 3 & 14 & 11 & & 4 & 11 & 59 \\
\hline в том чисте sonopontactumbt & & & & 3 & - & - & & 1 & 3 & 3 & 1 & 1 & & 15 \\
\hline $\begin{array}{l}\text { Птастины с ретушью со стимаи по одной } \\
\text { стороне }\end{array}$ & & 2 & 3 & 2 & 3 & 4 & & 8 & 11 & 4 & 3 & 3 & 4 & 47 \\
\hline в том घисте smnponтастипн & & & 1 & & 1 & & 2 & 1 & 2 & 4 & $\cdot$ & 3 & 1 & 15 \\
\hline $\begin{array}{l}\text { Птастины с ретуштю с брюетка по обеим } \\
\text { сторонам }\end{array}$ & & & & 1 & 2 & 2 & & 1 & 7 & 1 & 1 & 2 & 1 & 18 \\
\hline в том шисле sunpoпластины & & & & & & 1 & & & 1 & & & 1 & & 3 \\
\hline $\begin{array}{l}\text { Птастипь с ретушью с брнешха по одной } \\
\text { стороне }\end{array}$ & & & & 1 & & 2 & & 5 & 2 & 3 & 3 & & & 16 \\
\hline в том шисле sonроптастины & & & & 1 & & 2 & & 1 & 1 & & 1 & & & 6 \\
\hline Пластины с противолежащей ретушшю & & & & & & 3 & 1 & 2 & 1 & 3 & & & & 10 \\
\hline Пластнны с притупленньм краем & & & & & & & 1 & & 1 & 1 & 1 & 2 & 1 & 7 \\
\hline Птастины со скошенным хонцом & & & & & & & 1 & 1 & 1 & 1 & 1 & 1 & & 6 \\
\hline Птастины с прямосрезантьм концом & & & & & & & & & & 1 & 1 & & 1 & 3 \\
\hline Геометричесмие орудия: трапеции & & & & & & & & & 1 & & & & & 1 \\
\hline Пластины с выемчатым краем & & & & & & 1 & 1 & 1 & 3 & 1 & 3 & & 1 & 11 \\
\hline в том шисле минроптастины & & & & & & 1 & & 1 & 3 & & 2 & & & 7 \\
\hline Скребкн концевые на пластннах & & & & & & & 1 & & & & 1 & 1 & & 3 \\
\hline Сверла, проверткн, прокоткн & & & 1 & & 1 & 1 & 2 & 2 & 4 & 2 & 2 & 1 & & 16 \\
\hline Ребрнстые пластнны & & & & & & & & 2 & 1 & & 1 & & & 4 \\
\hline Широкне пластины архаичного вида & & & & & & 1 & & 4 & 1 & 6 & 3 & 4 & 5 & 24 \\
\hline Bcero & & & & & & & & & & & & & & 225 \\
\hline \multicolumn{15}{|c|}{ Изделия из отщепов } \\
\hline Cspeбsa: & 1 & 3 & 2 & 2 & 2 & 4 & 7 & 5 & 8 & 6 & 6 & 2 & 8 & 56 \\
\hline $\begin{array}{ll}\text { в том шисте: } & \text { высевне } \\
& \text { дисковидные } \\
\end{array}$ & & & & & & & & & & & & 1 & $\begin{array}{ll} \\
3 \\
\end{array}$ & \\
\hline Отщеты с краевойретушшю & 4 & 6 & 9 & 15 & 16 & 13 & 3 & 9 & 18 & 15 & 25 & 6 & 5 & 144 \\
\hline \multirow[t]{2}{*}{ Орудня долотовндной формы } & & & 1 & 2 & 1 & 1 & 1 & 2 & 2 & 2 & 2 & & 1 & 15 \\
\hline & & & & & & & 1 & 1 & 2 & & & & 1 & 5 \\
\hline $\begin{array}{l}\text { Двустороннеобрабо танпые наконечники } \\
\text { стрет }\end{array}$ & & & & & 1 & & & 1 & & & & & & 2 \\
\hline Сверла, проверткн, проколкн & & & & & 1 & 1 & & 1 & 2 & 1 & & & 1 & 7 \\
\hline Режущие орудия & & 1 & & & 1 & & & & 3 & & & 1 & & 6 \\
\hline Галечные орудия & 1 & & 4 & 1 & 2 & & 1 & & & & & 1 & 4 & 16 \\
\hline Плитчатые скребки & & & & & & & & & & - & & & & \\
\hline Зернотерки & & & & & 2 & & & & & & & & & 2 \\
\hline Шлифованные тесловндные топоры & & & & & 1 & & & & & & & & & 1 \\
\hline Миярочопперы & & & & & & & & & & & 1 & & & 1 \\
\hline Отбойники, отжиманй, ретушеры & & & & & & & & & & & & 2 & & 2 \\
\hline Кварцевме издетия & 3 & 2 & & 1 & 13 & 13 & 4 & 9 & 11 & 6 & 4 & 4 & & 70 \\
\hline Bcezo & & & & & & & & & & & & & & 327 \\
\hline Bcero & & & & & & & & & & & & & & 006 \\
\hline
\end{tabular}




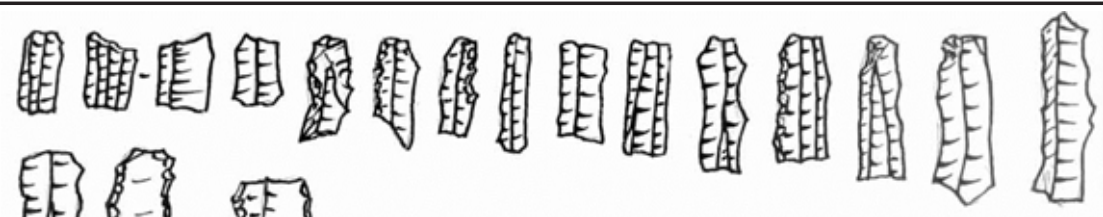
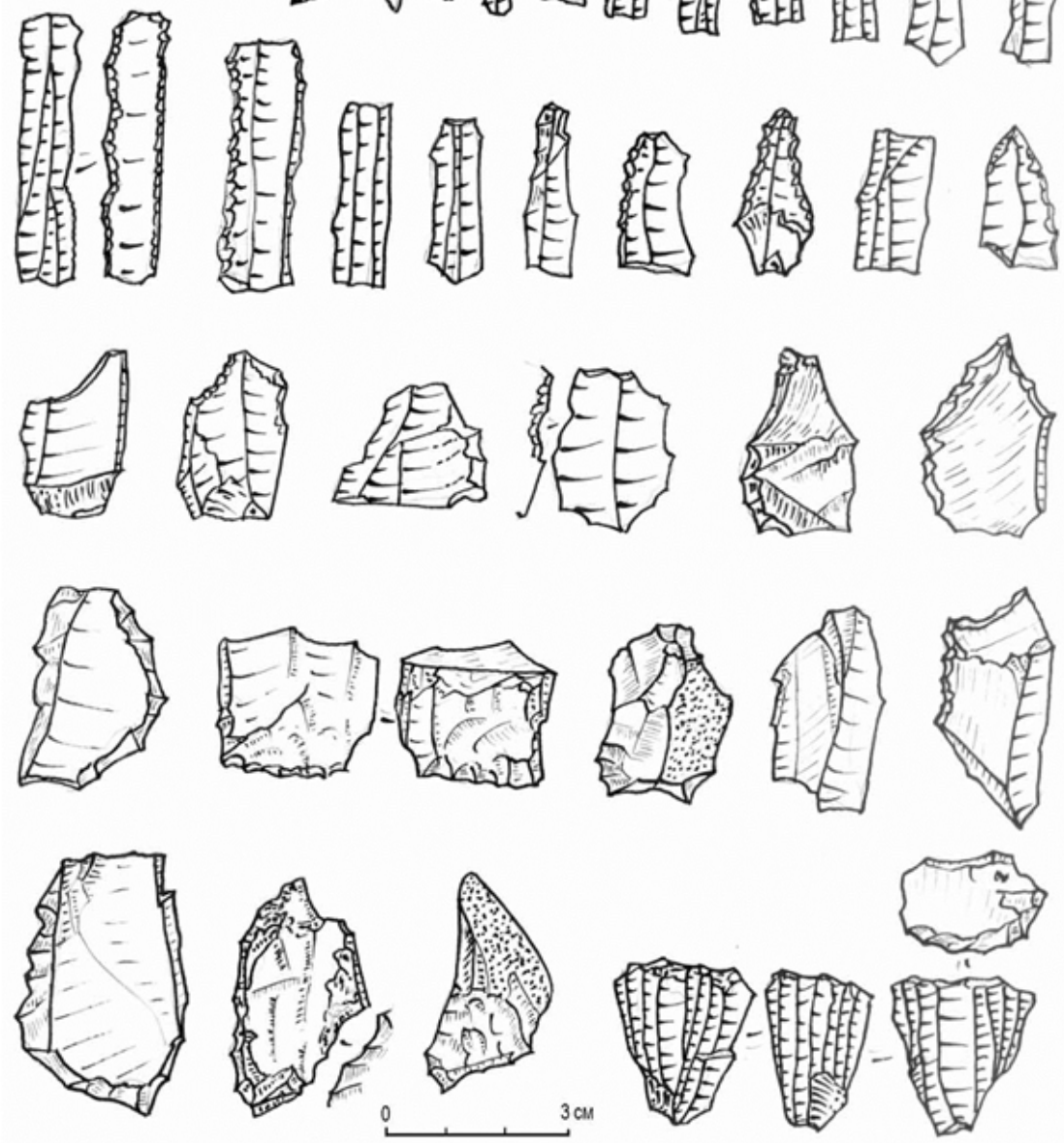

Рис. 3. Очилгор. Каменные изделия (верхний культурный горизонт)

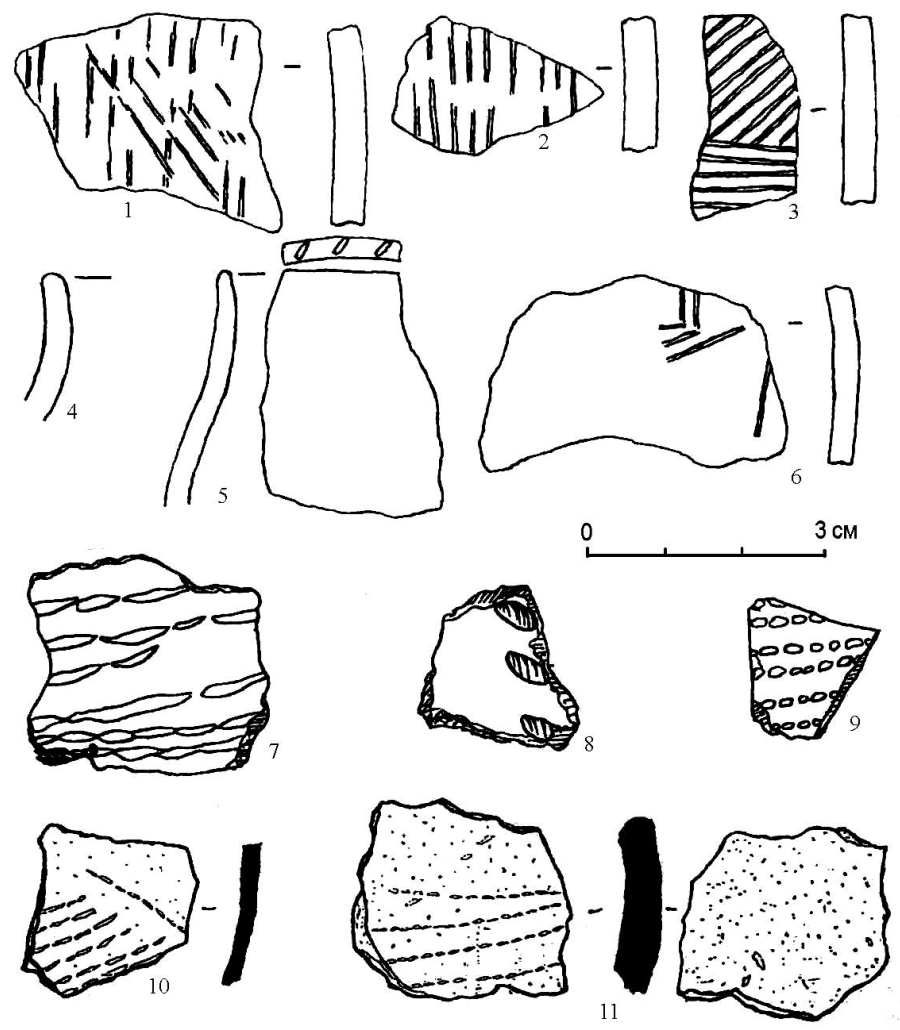

Керамика Сазаганской культуры 1-6 - Сазаган 2, 7-9 - Джангал 1, 10-11-Тепакул 3 


\author{
N.U. Holmatov, Candidate of Historical Science, assistant professor \\ Samarkand State University, Samarkand (Uzbekistan)
}

Annotation: This article is devoted to problems and perspectives of investigation of monuments, which dated to Neolith Age in the territory of Zarafshan valley. There are questions on the stem of new materials which is connected with culture genesis, cultural relations and also culture presentations were looked through.

Keywords: Tianshan Average Zarafshan; Samarkand parking, Sazagan 1, 2; Ayakagitma; scrapers; tools chisel shape cultural genesis.

\title{
УДК 902.2 \\ НЕОЛИТИЧЕСКАЯ СТОЯНКА АЯКАГИТМА (ВНУТРЕННИЕ КЫЗЫЛКУМЫ)
} (C) 2014

\author{
M.M. Хужнаназаров, кандидат исторических наук \\ Институт археологии Академии Наук Республики Узбекистан, Самарканд (Узбекистан) \\ К. Шимчак, доктор наук \\ Варшавский университет, Варшава (Польша) \\ Ф. Брунет, доктор наук \\ Нантер университет, Париж (Франция) \\ Х. Хошимов, докторант \\ Институт археологии Академии Наук Республики Узбекистан, Самарканд (Узбекистан)
}

Аннотация: Статья посвящена итогам изучения неолитической стоянки кельтеминарской культуры Аякагитма во Внутренних Кызылкумах. Анализируется керамический и кремневый инвентарь памятника.

Ключевые слова: Неолит; кельтеминарская культура; Зерафшан; Кызылкум; керамика; кремневый инвентарь.

Территория Узбекистана является одним из богатейших регионов Центральной Азии, где было обнаружено много памятников эпохи неолита. Они располагаются в трех основных физико-географических районах: в древних дельтах Амударьи и Зерафшана, во внутренних бессточных районах Кызылкумов и Устюрта, в предгорьях и горных долинах (Самаркандская область, Фергана). Большая часть их расположена в зоне пустынь и характеризуется крайне аридными условиями: малым количеством осадков, изреженным растительным покровом, практически отсутствием пресных поверхностных и высокой минерализацией грунтовых вод. Одним из таких памятников является неолитическая стоянка Аякагитма.

Памятник находится в юго-восточных Кызылкумах, в районе ныне не функционирующей древней дельты (плейстоцен - ранний голоцен) р. Зарафшан, с координатами 40³9'05' ' северной широты и 64³7'06' ' восточной долготы, высота над уровнем моря 210 м (Гиждуванский район, Бухарской области, рис. 1). Стоянка обнаружена участниками совместной узбекско-польской экспедиции в 1995 г. во время археологической разведки, проведенной в юго-восточных Кызылкумах в восточной части озера Аякагитма [1-7].

Как известно, древние дельты транзитных рек, во всяком случае, Амударьи и Зарафшана, стали объектом археологического исследования еще до 1940 г. ХХ столетия. Опубликованный в 1948 г. известный труд С.П. Толстова «Древний Хорезм» написан в основном по материалам довоенных исследований [8]. Эти неолитические памятники назывались С.П. Толстовым Кельтеминарской культурой (VII-IV тыс. до н.э.). Название они получили (как и две другие более поздние культуры этого района, тазабагьябская и амирабадская) по названию одного из исследованных здесь средневековых магистральных каналов.

Памятники этого периода сначала в древней Акчадарьинской дельте Амударьи, а затем позднее и на южных староречьях Зарафшана стали сразу же предметом специального исследования. Результаты исследований этих памятников, проведенных С.П. Толстовым [9], А.В. Виноградовым [9], Я.Г. Гулямовым и У.И. Исламовым [10], хорошо известны по публикациям (рис.2).

Кельтеминарские памятники известны сейчас почти на всей территории Кызылкумов (включая староречья Амударьи и Зарафшана), в среднем и нижнем
Левобережье Амударьи, на Узбое, Устюрте и в ряде районов Казахстана. Некоторые стоянки из неолитических комплексов Восточного Прикаспия (из района Балхан и Мангышлака) также можно отнести к кельтеминарской культурной общности [8; 12].

Комплексные работы Хорезмской экспедиции во главе с А.В. Виноградовым во внутренних Кызылкумах продолжались в течение десяти полевых сезонов (19651972, 1975, 1978 гг.). Материалы этих экспедиций широко известны по публикациям.

Новый этап в изучении каменного века Кызылкумов начался в 1995 г., когда организовалась узбекско-польская археологическая экспедиция на основе соглашения, подписанного между Институтом археологии АН РУз в Самарканде и Институтом археологии Варшавского университета. Главной научной целью этой экспедиции являлось исследование проблем, касающихся самых ранних стадий каменного века и расселение человека в регионе Кызылкумов. Полевые и лабораторные исследования, проведенные в течение десяти сезонов (19952005 гг.), дали много новых данных относительно самого археологического материала, получены радиоуглеродные даты образцов, а также материалы по геологическому, геоморфологическому и палеоэкологическому состоянию внутренних Кызылкумов.

Результаты исследований памятников каменного века и стоянки Аякагитма, полученные совместной экспедицией во главе с К. Шимчаком и М. Хужаназаровым, подтвердили ранее высказанное мнение о том, что в конце мезолита и неолита, то есть с VIII-VII по III тысячелетие до н.э. происходило интенсивное заселение и освоение человеком этих ныне пустынных районов. Вокруг стоянки Аякагитма, на староречьях Зарафшана и в других местах Внутренних Кызылкумов, зафиксированы сотни стоянок этого времени [6;7]. Кроме того, в восточной и северной частях впадины Аякагитма найдены и собраны палеолитические материалы, относящиеся к мустьерскому времени. Это, главным образом, отщепы средних размеров из коричневой окремненной породы, сильно сглаженные, патинизированные, с удлиненными изогнутыми отбивными бугорками.

При первом обследовании стоянки Аякагитма установлено, что она чрезвычайно богата находками и развеяна лишь частично. Предполагалось, что сохранилось, по меньшей мере, 35-40 см первоначальной мощности 